\title{
Tanggung Jawab Pengemudi Becak Sebagai Angkutan Lingkungan terhadap Penumpang Akibat Kecelakaan Lalu Lintas
}

\author{
Elfrida Ratnawati \\ Fakultas Hukum, Universitas Trisakti Jakarta, Jakarta \\ elfrida.r@trisakti.ac.id
}

\begin{abstract}
Abstrak
Tujuan dari penelitian ini adalah untuk menggambarkan tentang tanggung jawab pengemudi becak sebagai angkutan lingkungan atas kecelakaan akibat kelalaiannya dalam mengemudikan becak terhadap penumpang, karena seringkali terjadi kecelakaan ketika menggunakan alat angkut ini yang diakibatkan oleh kelalaian Pengemudi dan tidak ada pelaksanaan tanggung jawabnya. Apakah Undang-Undang Nomor 22 Tahun 2009 Tentang Lalu Lintas dan Angkutan Jalan mengatur tentang keberadaan kendaraan becak? dan bagaimana tanggung jawab pengemudi becak terhadap korban akibat kecelakaan?. Metode yang digunakan dalam penulisan ini adalah metode penelitian hukum normatif dengan data sekunder yaitu buku dan jurnal serta peraturan dan didukung oleh data primer, kemudian dianalisis secara deskriptif. Temuan dari penelitian ini adalah tidak ada pengaturan tentang pengoperasian angkutan tradisional becak dan masing-masing daerah mempunyai aturan di daerahnya masing-masing untuk mengatur tentang pengoperasian becak sebagai angkutan lingkungan. Pengemudi becak bertanggung jawab atas kelalaiannya yang menyebabkan penumpangnya menderita kerugian materiil maupun immaterial bagi penumpang.
\end{abstract}

Kata kunci : tanggung jawab; pengemudi becak; kelalaian; penumpang 
p-ISSN : 2541-2345, e-ISSN : 2580-8842

\title{
The Responsibility Of Becak Drivers As Environmental Transport to Passengers Due to Traffic Accidents
}

\author{
Elfrida Ratnawati \\ Faculty of Law, Trisakti University Jakarta, Jakarta \\ elfrida.r@trisakti.ac.id
}

\begin{abstract}
The purpose of this study is to describe the responsibility of a becak drivers as environmental transportation for accidents due to negligence in driving a pedicab for passengers, because accidents often occur when using this conveyance due to negligence of the driver and there is no implementation of his responsibility. Does Law Number 22 Year 2009 Regarding Traffic and Road Transportation regulate the existence of Pedicab Vehicles? and what is the responsibility of a becak drivers for victims of accidents? The method used in this paper is a normative legal research method with secondary data, namely books and journals and regulations and is supported by primary data, then analyzed descriptively. The findings of this study are that there is no regulation on the operation of traditional becak transportation and each region has rules in their respective regions to regulate the operation of becak as environmental transportation. The becak drivers is responsible for his negligence which causes the passengers to suffer material and immaterial losses for the passengers.
\end{abstract}

Keywords: responsibility; becak drivers; negligence; passenger

\section{PENDAHULUAN}

\section{A. Latar Belakang}

Kendaraan becak ini merupakan kendaraan tradisional Indonesia ${ }^{1}$ yang sering digunakan oleh umum, tidak hanya oleh kaum perempuan untuk pergi ke pasar, namun juga kaum laki-laki dan anak-anak untuk pergi ke tempat tujuan yang jaraknya dekat. becak sebagai angkutan, dalam mengantarkan penumpangnya dengan selamat sampai ketempat tujuan tertentu, hal ini terkait dengan definisi pengangkutan yaitu persetujuan dengan mana pengangkut mengikatkan diri untuk menyelenggarakan pengangkutan barang dan/atau penumpang dari suatu tempat ketempat tujuan tertentu dengan selamat, dan

${ }^{1}$ Riri Dwi Vivindra, Syamsir dan Nurman. 2015. Eksistensi Bendi dalam Perspektif Budaya di Kota Padang, Provinsi Sumatera Barat, Jurnal Humanus, Vol. XIV No. 1 Tahun 2015, Universitas Negeri Padang, 2015, Padang, hal.71-79. 
pengirim atau penumpang mengikatkan diri untuk membayar biaya pengangkutan. $^{2}$ Berdasarkan definisi pengangkutan, dimana pengangkut mengikatkan diri untuk menyelenggarakan pengangkutan barang dan/atau orang dari suatu tempat ke tempat tujuan tertentu dengan selamat.

Banyaknya becak merupakan lambang kemiskinan di negara-negara sedang berkembang. Menjadi pengemudi becak merupakan lapangan kerja terakhir yang dipilih seseorang karena tidak membutuhkan keahlian khusus untuk bisa mengemudikan becak, yang terpenting sehat secara jasmani dan kuat untuk mengayuh becaknya. Selanjutnya mencari pengusaha yang meminjamkan becak dengan bayaran tertentu. ${ }^{3}$

Harian nasional online di Ambon memberitakan, bahwa Pengadilan Negeri Ambon menjatuhkan hukuman penjara 18 bulan kepada pengemudi becak bernama Rasilu, dikarenakan dianggap bersalah menyebabkan penumpangnya meninggal dunia akibat kecelakaan pada tanggal 22 Februari 2019. Pembelaan Rasilu adalah sampai terjadinya kecelakaan dikarenakan di jalan raya menghindari mobil yang berkecepatan tinggi di tengan hujan deras. Atas kecelakaan tersebut, Rasilu, pengemudi becak bertanggung jawab secara perdata yaitu membayar biaya pengobatan penumpang yang akhirnya meninggal dunia dan tanggung jawab secara pidana yaitu menjalani hukuman penjara selama 18 bulan di tahanan. Kecelakaan antara sepeda motor dan becak terjadi juga di Banda Aceh pada tanggal 27 Juli 2019 yang menyebabkan penumpang meninggal dunia. Kecelakaan terjadi karena becak yang membawa banyak barang itu ditabrak dari samping oleh motor, dan atas kejadian kecelakaan ini, pengemudi becak dilaporkan ke kepolisian.

Kebutuhan akan alat transportasi sangat dirasakan dalam menunjang mobilitas seseorang setiap harinya, terutama di zaman modern seperti sekarang. Ada berbagai jenis alat transportasi yang bisa dijumpai di zaman sekarang baik itu yang modern (mobil, motor, pesawat, kereta api, dan lainlain) atau tradisional (bendi, becak, dan lain-lain). Perkembangannya banyak alat transportasi yang mulai bertransformasi mengikuti perkembangan zaman, seperti kereta/mobil listrik, bahkan yang terbaru adalah mobil yang bisa terbang. Namun, di tengah semakin modernnya alat transportasi, masih

${ }^{2}$ H.M.N Purwosutjipto, Pengertian Pokok Hukum Dagang Indonesia, jilid 3, ( Jakarta :

Djambatan, 1995 ), hal 2.

${ }^{3}$ Ully Muzakir, Zainal Abidin Suarja, Becak Argo Sebagai Sumber Penghasilan Dan Transportasi Baru Di Kota Madani, Jurnal Genta Mulia Vol VII No 2. Juli-Desember, STKIP Bina Bangsa Meulaboh, 2016, Aceh Barat hal 93. 
p-ISSN : 2541-2345, e-ISSN : 2580-8842

banyak dijumpai di beberapa daerah sarana transportasi tradisional yang masih bertahan sampai saat ini, salah satunya adalah becak. ${ }^{4}$

Becak tradisional adalah salah satu kendaraan tidak bermotor yang masih bertahan dalam melakukan pengangkutan bagi masyarakat khususnya di daerah pedesaan dan beberapa kawasan di perkotaan, seperti alun-alun, depan mall dan pasar, yang beroperasi tanpa aturan sehingga sering mengganggu aktivitas lalu lintas di sekitarnya. ${ }^{5}$ Hampir hilangnya moda transportasi becak di berbagai kota di Indonesia, merupakan salah satu contoh bahwa becak sebagai alat transportasi tradisonal sudah mulai ditinggalkan, karean tidak adanya pengelolaan yang baik dan pergeseran kebutuhan masyarakat akan alat transportasi yang murah dan cepat.

Sebagian becak bukan milik sendiri, becaknya milik majikan dengan sistem setoran. Umumnya becak setoran inilah yang belum dimodifikasi menjadi bentor. Sedang yang becaknya milik sendiri kondisi becaknya jelek tidak layak pakai dan memprihatinkan. ${ }^{6}$ Kondisi angkutan tradisinal di Indonesia masih jauh dari harapan. Alat transporatsi tradisonal tersebut ratarata tidak dikelola dengan baik. Untuk mengelola transpotasi tradisional menjadi lebih baik agar dapat mengikuti perkembangan zaman yang semakin modern. Perlu adanya campur tangan dari pemerintah melalui regulasi yang mendukung keberadaan dan perlindungan terhadap transportasi tradisonal. Perlindungan tersebut juga harus mengatur perlindungan terhadap pengemudi dan penum,pang transportasi tadisional.

Sebelumnya, becak dan andong digunakan masyarakat sebagai alat transportasi yang memiliki peranan penting dalam mendukung aktivitas dan pergerakan masyarakat. Namun saat ini peran becak dan andong sebagai alat transportasi umum sudah mulai hilang dan bergeser menjadi alat transportasi wisata karena keunikannya yang masih dipertahankan dan jarang dijumpai di

${ }^{4}$ Baihaqi Hendri Mangatta, Strategi Adaptasi Tukang Becak Dalam Kehidupan Sosial Ekonomi (Studi Kasus Tukang Becak di Kelurahan Bontobiraeng Kecamatan Mamajang Kota Makassar), Jurnal Holistik Tahun IX No. 18/Juli-Desember 2016, Fakultas Ilmu Sosial dan Ilmu Politik Universitas Sam Ratulangi, 2016, Manado, hal.2

${ }^{5}$ Putu Agus Jegantara Wiguna, Arinto Nugroho, Aturan Penggunaan Becak Tradisional di Kota Surabaya, Jurnal Novum, Vol. 4. No.1, Fakultas Hukum Universitas Negeri Surabaya, 2017, Surabaya hal 1.

${ }^{6}$ Sunaryo, Margianto, dan Usman Ali, Pelestarian dan Pembinaan Usaha Jasa Ojek Dokar dan Becak di Pasar Tradisional Malang, Jurnal Semar Vol. 5 No. 1 November, Universitas Sebelas Maret, 2016,Surakarta, hal 93. 
era modern ini. Keberadaannya pun juga selalu berkaitan dengan kegiatan pariwisata terutama tempat-tempat wisata budaya. Kota Yogyakarta merupakan salah satu kota yang masih mempertahankan keberadaan transportasi umum tidak bermotor seperti becak dan andong di tengah perkembangan kota Yogyakarta menjadi kota metropolitan. Adanya peran serta dari pemerintah dan masyarakat di kota Yogyakarta dalam memberdayakan transportasi tradsional sebagai pendukung di sektor pariwisata menjadi nilai lebih dalam pengelolaan transportasi tradisonal. Hal ini seharusnya juga diikuti dengan bagaimana melindungi pengemudi dan penumpang transportasi tradisional.

Banyak kejadian kecelakaan lalu lintas yang terjadi antara becak dengan transportasi darat lainnya, apakah becak yang menabrak atau ditabrak oleh transportasi lain. Contohnya saja kasus kecelakaan di Jalan Tubagus Angke, Jembatan Dua, Tambora, Jakarta Barat, becak yang sedang mengangkut penumpang diseruduk mobil. Akibat kecelakaan ini, pengemudi dan penumpang becak tersebut tewas di tempat. Sementara itu, mobil yang menabrak becak tersebut melarikan diri. Kasus kecelakaan becak lainnya adalah sepeda motor Scopy menabrak pengayuh becak hingga pengendara Scopy dan pengayuh becak dan penunpangnya mengalami luka-luka dan harus dilarikan ke rumah sakit terdekat, Senin (24/4/2017) sekira pukul 03.30 wib. ${ }^{7}$ Kejadian berikutnya adalah becak menabrak motor yang sedang melintas di jalan raya, menyebabkan pengendara motor terluka akibat jatuh ditabrak becak demikian pula pengemudi becak. ${ }^{8}$ Berdasarkan pemaparan kasus kecelakaan di atas, menjadi suatu pemikiran untuk penelelitian tentang bagaimana tanggung jawab dari pengemudi becak terhadap penumpangnya yang menjadi korban kecelakaan lalu lintas.

Penelitian tentang tanggung jawab pengemudi becak sebagai angkutan lingkungan terhadap penumpang akibat kecelakaan lalu lintas berbeda dengan penulisan-penulisan di jurnal yang dirujuk sebagai referensi dalam penulisan artikel ini. Sebagian besar jurnal yang dirujuk, penulisannya menelaah tentang keberadaan becak, fungsi becak, dan tidak membahas tentang bentuk tanggung jawab pengemudinya apabila terjadi kecelakaan lalu lintas dan pendekatannya yaitu peraturan lalu lintas dan angkutan jalan.

\section{B. Perumusan Masalah}

Dilihat dari penelitian hukum, permasalahan adalah hal sesuatu yang tidak cocok antara teori dengan praktek, antara hukum atau peraturan

7 http://rakyatindependen.com/pengendara-sepeda-motor-scopy-nabrak-becak-dari-belakangdi-jalan-raya-kapas/

${ }^{8}$ Kasus tabrakan Becak dan Motor di Yogyakarta, Youtube, https://www.youtube.com/watch?v=X5W7dLXQ8nM 
p-ISSN : 2541-2345, e-ISSN : 2580-8842

perundang-undangan dengan kenyataan, atau keinginan yang dicapai atau dengan kata lain tidak cocoknya antara das sollen dan das sein. Berdasarkan uraian yang dikemukakan dalam latar belakang, maka dapat dirumuskan pokok permasalahan dalam penulisan ini adalah sebagai berikut :

1. Bagaimana pengaturan hukum tentang keberadaan becak di indonesia?

2. Bagaimana perlindungan hukum bagi para pihak sebagai korban akibat kelalaian pengemudi becak?

\section{Metode Penelitian}

Metode Penelitian yang digunakan dalam penulisan artikel ini adalah penelitian hukum untuk mencari pemecahan atas isu hukum yang timbul yaitu memberikan perskripsi atas isu hukum yang diajukan. ${ }^{9}$ Metode penelitian hukum adalah "menemukan kebenaran, koherensi, yaitu adakah aturan hukum sesuai norma hukum dan adakah norma yang berupa perintah atau larangan sesuai dengan prinsip hukum, serta apakah tindkan seseorang sesuai dengan norma hukum (bukan hanya sesuai dengan aturan hukum) atau prindip hukum. ${ }^{10}$

Jenis penelitian hukum yang digunakan dalam penulisan ini adalah penelitian hukum normatif yaitu penelitian yang dilakukan dengan cara mengkaji peraturan perundang-undangan yang berlaku atau diterapkan terhadap suatu permasalahan hukum tertentu. ${ }^{11}$ Penelitian hukum normatif ini mengacu pada kaidah-kaidah, norma-norma atau asas-asas hukum, dan data yang diperoleh melalui studi kepustakaan dan penelitian ini menggunakan peraturan perundang-undangan ${ }^{12}$ mengenai ketentuan tentang tanggung jawab pengemudi becak kepada penumpangnya akibat kecelakaan lalu lintas. Sifat penelitian ini adalah deskriptif analisis yang menggambarkan secara jelas tentang objek penelitian berdasarkan norma hukum dan perundang-undangan yang berlaku, kemudian dianalisis untuk mencari jawaban atas permasalahan.

Data yang diperlukan dalam penulisan ini adalah data primer yang didapatkan langsung oleh peneliti dari sumber data untuk menunjang dan melengkapi analisis data sekunder, yaitu wawancara langsung kepada narasumber pengemudi becak dan penegak hukum berlalu lintas,yaitu polisi.

\section{PEMBAHASAN}

\section{A. Perkembangan Angkutan}

${ }^{9}$ Dyah Ochtorina Susanti dan A'an Efendi. 2014, Penelitian Hukum (Legal Research), Jakarta: Sinar Grafika. hal.1.

${ }^{10}$ Peter Mahmud Marzuki, 2007, Penelitian Hukum, Jakarta, Kencana, hal 47.

${ }^{11}$ Soedjono dan H Abdurahman, 2003, Metode Penelitian Hukum, .Jakarta, Rineka Cipta. hal 56.

\footnotetext{
${ }^{12}$ Soerjono Soekanto, 2007, Pengantar Penelitian Hukum, Jakarta, UI, hal 51.
} 
Perkembangan di bidang pengangkutan mendorong perkembangan pendidikan di bidang ilmu dan teknologi pengangkutan modern, sarana dan prasarana angkutan modern, dan hukum pengangkutan modern. ${ }^{13}$ Pengangkutan juga memperhatikan keadaan geografis Indonesia berupa daratan yang terdiri dari beribu-ribu pulau besar dan kecil, dan berupa perairan yang terdiri dari sebagian besar laut dan sungai serta danau yang memungkinkan pengangkutan dilakukan melalui darat, perairan, dan udara guna menjangkau seluruh wilayah negara. Kondisi angkutan tiga jalur tersebut mendorong dan menjadi alasan penggunaan alat pengangkut modern yang digerakan secara mekanik. ${ }^{14}$ Transportasi merupakan salah satu faktor terpenting dalam menaikkan roda pertumbuhan ekonomi di Indonesia, karena dengan lancarnya transportasi berarti kelancaran perekonomian suatu negara dapat terjamin, ditunjang dengan canggihnya transportasi sehingga mobilitas kegiatan semakin cepat dan mendukung perekonomian. Transportasi merupakan alat angkut yang tak dapat dipisahkan dengan sistem transportasi nasional yang dinamis mengadaptasi kemajuan di masa depan, mempunyai karakteristik yang mampu menjangkau seluruh pelosok wilayah daratan dan memadukan transportasi lainnya sebagai penghubung wilayah. Untuk menunjang mobilitas masyarakat, dapat pula ditawarkan pilihan moda, namun yang harus diperhatikan adalah karakteristik masing-masing moda yang harus dipertemukan dengan tuntutan kebutuhan masyarakat. ${ }^{15}$

Meski sistem transportasi di Jakarta menuju ke arah yang semakin modern namun Ibu kota sesungguhnya masih memiliki angkutan tradisional peninggalan masa lalu yang masih bertahan hingga sekarang, ${ }^{16}$ namun keberadaan angkutan tradisional saat ini harus bersaing dengan angkutan modern lainnya seperti bus, taksi, bus transjakarta, hingga rencana pembangunan monorel yang sampai saat ini belum terealisasikan, salah satu angkutan tradisional yang hingga saat ini masih bertahan ialah becak.

Jika dalam penyelenggaraan kegiatan angkutan tersebut tidak berjalan dengan semestinya, maka pihak yang bertanggung jawab atas keselamatan jiwa dari para penumpangnya adalah pengusaha angkutan, karena penumpang telah melakukan pembayaran biaya tertentu untuk pengangkutan tersebut, oleh karena itu sudah sewajarnya bagi pengusaha angkutan khususnya bemo untuk berkewajiban menyelenggarakan pengangkutan barang dan/atau orang

\section{Bakti, hal 8 .}

${ }^{13}$ Abdulkadir Muhammad, 1998, Hukum Pengangkutan Niaga, Bandung, PT. Citra Aditya

${ }^{14}$ Ibid, hal 7.

${ }^{15}$ Suwardjoko Wardani, 2002, Pengelolaan Lalu Lintas dan Angkutan Jalan, Bandung, hal. 5

16 Ibid. 
dari suatu tempat ke tempat tujuan tertentu dengan selamat. Tulisan ini akan membahas tentang tanggung jawab dari pengemudi becak yang karena kelalaiannya mengakibatkan penumpangnya meninggal dunia, luka berat ataupun ringan.

\section{B. Sejarah Becak di Indonesia}

Sama seperti Awal mula becak ${ }^{17}$, tak jelas juga kapan becak dikenal di Indonesia. Lea Jellanik dalam bukunya yang berjudul Seperti Roda Berputar, menulis bahwa becak didatangkan ke Batavia dari Singapura dan Hongkong pada 1930-an. Jawa Shimbun terbitan 20 Januari 1943 menyebut becak diperkenalkan dari Makassar ke Batavia Akhir 1930-an. Ini diperkuat dengan catatan perjalanan seorang wartawan Jepang ke berbagai daerah di Indonesia, termasuk Makassar. Dalam catatan berjudul "Pen to Kamera" terbitan 1937 itu disebutkan, becak ditemukan orang Jepang yang tinggal di Makassar, bernama Seiko-san yang memiliki toko sepeda. Karena penjualan seret, pemiliknya memutar otak agar tumpukan sepeda yang tak terjual bisa dikurangi. Dia membuat kendaraan roda tiga, dan terciptalah becak.Becak ${ }^{18}$ (dari bahasa Hokkien: be chia "kereta kuda") adalah suatu moda transportasi beroda tiga yang umum ditemukan di Indonesia dan juga di sebagian Asia.

Kapasitas normal becak adalah dua orang penumpang dan seorang pengemudi. Masuk ke Indonesia ${ }^{19}$ pertama kali pada awal abad ke-20 untuk keperluan pedagang Tionghoa mengangkut barang. Di tahun 1937, demikian tertulis dalam Star Weekly, becak dikenal dengan nama "roda tiga" dan kata betjak/betja/beetja baru digunakan pada 1940 ketika becak mulai digunakan sebagai kendaraan umum. Awalnya pemerintah kolonial Belanda ${ }^{20}$ merasa

https://id.wikibooks.org/wiki/Profil_Becak_di_Indonesia/Sejarah_perkembangan_becak_di_Indone $\underline{\text { sia }}$, Sejarah Becak yang Tak Pernah Mati, Diaskes, Tanggal. 1 Agustus 2017

https://id.wikibooks.org/wiki/Profil_Becak_di_Indonesia/Sejarah_perkembangan_becak_di_Indone sia , Sejarah Becak, Diaskes, Tanggal. 1 Agustus 2017

${ }^{19}$ https://id.wikibooks.org/wiki/Profil_Becak_di_Indonesia/Sejarah_perkembangan_becak_di $\frac{\text { Indonesia }}{20}$, Becak Vs Telovaxi, Diaskes, Tanggal. 1 Agustus 2017

https://id.wikibooks.org/wiki/Profil_Becak_di_Indonesia/Sejarah_perkembangan becak_di_Indone sia , Mengayuh Sejarah Becak, Diaskes, Tanggal. 1 Agustus 2017 
senang dengan transportasi baru ini. Namun belakangan pemerintah melarang keberadaan becak karena jumlahnya terus bertambah, membahayakan keselamatan penumpang, dan menimbulkan kemacetan. Jumlah becak justru meningkat pesat ketika Jepang datang ke Indonesia pada 1942. Kontrol Jepang yang sangat ketat terhadap penggunaan bensin serta larangan kepemilikan kendaraan bermotor pribadi menjadikan becak sebagai satu-satunya alternatif terbaik moda transportasi di kota-kota besar seperti Jakarta dan Surabaya. Bahkan penguasa membentuk dan memobilisasi kelompok-kelompok, termasuk tukang becak, demi kepentingan perang melalui pusat pelatihan pemuda, yang mengajarkan konsep politik dan teknik organisasi. Becak dilarang untuk beroperasi di Jakarta karena alasan tidak manusiawi atas dasar Perda 11 Tahun 1988, yang di dalamnya tercantum bahwa kendaraan resmi hanya kereta api, taksi, bis, dan angkutan roda tiga bermotor.

Becak setelah berkembang di Batavia/Jakarta kemudian berkembang ke Surabaya pada tahun 1940, Jawa Shimbun ${ }^{21}$ terbitan 20 Januari 1943 menyebut becak diperkenalkan dari Makassar ke Batavia akhir 1930-an. Pasca perang, ketika jalur dan moda transportasi kian berkembang, becak tetap bertahan. Bahkan ia menjadi transportasi yang menyebar hampir di seluruh Indonesia. Pada pertengahan hingga akhir 1950-an ada sekira 25.000 hingga 30.000 becak di Jakarta. Jumlah becak membengkak dan pada tahun 1966 jumlah becak ada 160 ribu -jumlah tertinggi dalam sejarah.

Saat Gubernur Ali Sadikin menjadi Gubernur di Jakarta, mengeluarkan aturan mengenai larangan total angkutan yang memakai tenaga manusia, membatasi beroperasinya becak, dan mengadakan razia mendadak di daerah bebas becak. Kebijakan serupa dilanjutkan oleh gubernur-gubernur berikutnya: Suprapto, Wiyogo Atmodarminto, Suprapto, dan Sutiyoso. Becak dianggap biang kemacetan, simbol ketertinggalan kota, dan alat angkut yang tak manusiawi. Di sisi lain, becak juga mulai menghadapi pesaing dengan kehadiran ojek motor, mikrolet, dan metromini. Pada 1980, misalnya, pemerintah mendatangkan 10.000 minica (bajaj, helicak, minicar) untuk menggantikan 150.000 becak. Pemerintah ketika itu memprogramkan para tukang becak beralih profesi menjadi pengemudi kendaraan bermotor itu. Bahkan pemerintah menggaruk becak dan membuangnya ke Teluk Jakarta untuk rumpon, semacam rumah ikan. Karena sulit, Gubernur Suprapto sampai bilang: "becak-becak akan punah secara alamiah."

Di Indonesia becak merupakan salah satu lapangan kerja yang mudah untuk dimasuki, sehingga kalau tidak dikendalikan jumlah becak akan berkembang dengan luar biasa. Jumlah pengayuh becak biasanya berkurang 
p-ISSN : 2541-2345, e-ISSN : 2580-8842

pada musim panen, ataupun pada saat nelayan turun kelaut, pada musim angin nelayan yang tidak melaut akan menjadi pengayuh becak sebagai alternatif ${ }^{22}$.

\section{Pengaturan Hukum Keberadaan Becak Di Indonesia}

Menurut Undang-Undang No. 22 Tahun 2009 tentang Lalu Lintas dan Angkutan Jalan tidak ada pasal yang secara tegas melarang beroperasinya angkutan umum beroda dua atau beroda tiga. Dalam pasal 138 ayat (3) UU No. 22/2009 hanya disebutkan bahwa angkutan umum orang dan/atau barang hanya dilakukan dengan Kendaraan Bermotor Umum. Sebelum UU No. 22/2009 disahkannya, UU No. 14 Tahun 1992 tentang Lalu Lintas dan Angkutan Jalan dan PP No. 41 Tahun 1993 tentang Angkutan Jalan menyebutkan bahwa pengangkutan orang dengan kendaraan umum dilakukan dengan menggunakan mobil bus atau mobil penumpang ${ }^{23}$.

UU No 22/2009 menyatakan semua peraturan dalam Peraturan Pemerintah No. 41/1993 tentang Angkutan Jalan dinyatakan tetap berlaku sepanjang tidak bertentangan atau belum diganti dengan yang baru. Selain peraturan perundang-undangan di tingkat pusat, dasar hukum angkutan umum juga banyak diatur melalui peraturan daerah di masing-masing wilayah. Beberapa daerah membolehkan beroperasinya angkutan umum roda dua (ojek sepeda motor dan ojek sepeda) dan roda tiga (bajaj dan bemo), sementara daerah lainnya sudah melarang.

Becak tradisional atau kayuh di Yogyakarta sudah ditetapkan menjadi angkutan tradisonal dan sudah diatur dalam Perda Daerah Istimewa Yogyakarta Nomor 5 Tahun 2016, yang mengatur seputar spesifikasi teknis hingga pelestariannya ${ }^{24}$. Total jumlah becak kayuh di Kota Yogyakarta diperkirakan sekitar 8.600 unit. Dinas Perhubungan terus melakukan pendataan ulang dengan secara rutin diberikan pembekalan karena sudah diatur regulasi, bahwa setiap kendaraan tidak bermotor di Kota Yogyakarta wajib memiliki tanda nomor kendaraan tidak bermotor atau semacam plat nomor kendaraan. Pengaturan becak di Bogor, walaupun sebagai alat angkutan tidak bermotor namun ditetapkan untuk menerapkan adanya SIM dan STNK bagi pengemudinya serta ditetapkan trayek dan uji kelayakan

\footnotetext{
${ }^{22}$ Yuni Astuti, "Eksistensi Angkutan Becak dalam Perkembangan Transportasi di Yogyakarta,” Jurnal INA- Rxiv, Intitut Teknologi Bandung, 2016, Bandung, hal 1-8.

${ }^{23}$ Meta Suryani dan Anis Mashdurohatun, "Penegakan Hukum Terhadap Eksistensi Becak Bermotor (Bentor) Berdasarkan Undang-Undang Nomor 22 Tahun 2009 Tentang Lalu Lintas dan Angkutan Jalan," Jurnal Pembaharuan Hukum, Vol III No. 1 Januari-April 2016, Fakultas Hukum Universitas Islam Sultan Agung, 2016, Semarang, hal 21-38.

${ }^{24}$ Sunaryo, Margianto dan Usman Ali, Op.Cit
} 
berdasarkan instrument hukum peraturan daerah setempat, sebagai tujuan untuk mengurangi jumlah angkutan tersebut.

Angkutan becak dapat dikatakan suatu angkutan yang melakukan kegiatan pengangkutan orang dan atau barang sama seperti kendaraan umum, namun tidak bermotor. Padahal, apabila menilik unsur-unsur kendaraan umum seperti yang terdapat di dalam Pasal 1 butir (10) yang dapat dikatakan kendaraan umum adalah setiap kendaraan yang digunakan untuk angkutan barang dan/atau orang dengan dipungut bayaran. Angkutan becak lebih memenuhi unsure dalam Pasal 1 butir (9) UULLAJ dan penjelasan Pasal 1 butir (9) UULLAJ yang menyatakan kendaraan tidak bermotor adalah setiap kendaraan yang digerakkan oleh tenaga manusia dan/atau hewan, dan di sini tidka dikatakan mempunyai fungsi sebagai kendaraan umum, maka jika dianalisis becak hanya memenuhi beberapa unsur saja, yaitu :

a. angkutan becak dipergunakan oleh umum dalam hal ini adalah penumpang;

b. angkutan becak memungut bayaran dari penumpang;

c. angkutan becak merupakan angkutan beroda tiga.

Namun tidak memenuhi persyaratan sebagai :

a. angkutan yang mempunyai mesin atau bermotor yang menggunakan mesin dua atau empat tak,

b. tidak mempunyai ijin trayek yang umum dan unsur lainnya sebagai syarat suatu angkutan umum;

Melihat dari unsur-unsur tersebut, tampak jelas bahwa angkutan becak tidak termasuk kedalam kategori kendaraan umum. Oleh karena angkutan tersebut tidak termasuk kedalam kategori kendaraan umum, maka ketentuan privat di dalam Pasal 34 sampai dengan Pasal 48 UULLAJ tidak dapat diberlakukan terhadap angkutan becak. Menurut hukum pengangkutan apabila terjadi kerugian, maka yang bertanggung jawab ialah pengangkut. Artinya tanggung jawab pengangkut dimulai sejak penumpang dan/atau barang dimuat ke dalam alat pengangkut atau barang dibongkar dari alat angkut atau diserahkan kepada penerima karena tanggung jawab merupakan suatu keharusan bagi seseorang untuk melaksanakan dengan selayaknya apa yang diwajibkan kepadanya. Pengaturan tentang tanggung jawab pengangkutan dalam Undang-Undang No. 22 Tahun 2009 tentang Lalu Lintas dan Angkutan Jalan terdapat mulai dari pasal 186 dan seterusnya tidak berlaku untuk angkutan becak. Kesimpulannya dalam undang-undang ini tidak mengatur tentang angkutan becak.

\section{Tanggung Jawab Pengemudi Becak kepada Penumpangnya}

Banyak kecelakaan terjadi akibat dari kelalaian pengemudi becak, apakah itu penumpangnya sendiri maupun pihak ketiga yang menderita luka atau sampai pada kematian dikarenakan kelalaian dari pengemudi becak. Pemerintah kota dan daerah berusaha untuk terus meredam tingkat kecelakaan akibat dari kelalain pengemudi becak tersebut. Salah satu usaha untuk mengurangi jumlah becak itu dilakukan karena dianggap turut menyumbang 
kesemrawutan dan kemacetan lalu lintas. Sebagian becak bisa saja beroperasi di ruas arteri dan jalan protocol. Seharusnya angkutan umum bertenaga manusia itu hanya boleh beroperasi di kompleks atau permukiman sebagai angkutan umum pengumpan.

Usaha pengurangan becak dilakukan secara bertahap dengan cara membeli becak-becak yang sudah tidak laik jalan. Pokok permasalahan utama dalam pengangkutan tradisional becak ini adalah, bagaimana perlindungan hukum terhadap para korban, baik itu pihak ketiga maupun konsumennya sendiri, apabila terjadi kecelakaan, terjadi perbuatan melawan hukum, terjadi wanprestasi, dan hal lainnya yang merugikan orang lain. Angkutan tradisional becak ini di Indonesia sangat di istimewakan, antara lain:

a. Memiliki imunitas sebagai angkutan tradisional

Polisi selalu menghimbau agar pengguna jalan selalu berhati-hati dan konsentrasi dalam mengemudi, walaupun tidak tertulis, namun mempunyai tujuan tertentu yaitu untuk selalu berjaga-jaga apabila ada becak yang sewaktu-waktu melintas. Kadang, pengemudi becak dapat dengan bebasnya melanggar aturan marka jalan, dengan nekatnya menerobos jalan satu arah. Namun sudah menjadi suatu kebiasaan dimana pengendara lainnya tidak mempermasalahkannya, bahkan tanpa sadar menghindar dari becak yang melawan arah jalan tersebut, agar tidak terjadi kecelakaan. Kejadian ini sering terjadi di perempatan besar dan ada polisi sebagai penjaga lalu lintas, namun tidak ada tindakan apa pun yang dilakukan aparat selain hanya membiarkan becak itu lewat.

b. Membawa angkutan melebihi kapasitas muatan

Jika dilihat dari konstruksinya, becak bukan lah kendaraan yang baik. Terutama karena posisi pengemudi di belakang menyebabkan kurang sempurnanya penglihatan ke depan. Namun desain dua roda di depan untuk menopang bagian muka, justru membuat tukang becak mampu mengangkut barang bawaan yang banyaknya melebihi kapasitas muatan.

c. Tak perlu pakai SIM

Pengemudi becak tidak memerlukan SIM dan STNK ketika menggunakannya untuk bekerja.

d. Bebas tilang

Becak juga kendaraan yang aman dari tilang. Jadi, tak perlu khawatir jika ada razia, sekalian lawan arus juga takkan kena tilang. Aturan tentang kendaraan becak ini cukup rumit.

e. Tidak ada aturan tentang sanksi pelanggaran dan penegakan hukum Becak dapat dikatakan kendaraan penumpang, dapat dikatakan transportasi umum, namun mengapa kedudukannya begitu ringan di mata hukum? Misalnya saja apabila terjadi kecelakaan dan penumpang yang diangkutnya meninggal dunia, atau pihak ketiga mengalami kerugian materiil dan immaterial. Hal ini dikarenakan tidak ada aturan tentang penindakan 
terhadap pengemudi angkutan becak ketika melakukan pelanggaran, jadi tidak ada law enforcement atau upaya untuk penegakan hukum.

f. Tidak ada ganti rugi

Yang ada musyawarah dan mufakat secara kekeluargaan apabila terjadi kelalaian terhadap pihak ketiga penumpangnya

Selama ini berdasarkan berita-berita yang diperoleh baik itu media elektronik atau cetak, terkadang pengemudi becak yang telah menyebabkan kerugian baik materil maupun immateriil terhadap penumpangnya tidak menjalankan tanggung jawabnya baik itu secara keperdataan dalam bentuk ganti rugi maupun pidana dalam bentuk hukuman penjara setelah melalui proses pelaporan kepada pihak kepolisian dan diadili di pengadilan. Namun dengan berkembangnya waktu, proses penegakan hukum atas kelalaian pengemudi becak sehingga mengakibatkan kerugian baik materiil maupun immateriil, menuntut adanya pertanggungjawaban dari pengemudi becak atas perbuatannya, baik itu tanggung jawab secara perdata maupun pidana, seperti paparan cerita tentang kasus pengemudi becak di Ambon yang bertanggung jawab baik secara perdata maupun pidana.

Seringkali pengemudi becak selalu dianggap manusia yang lemah, berpenghasilan kecil dan tidak berkecukupan, sehingga apabila melakukan kesalahan, selalu ada unsur pemakluman dan pemaaf, walaupun pihak korban menderita luka berat sekalipun. Berdasarkan hal di atas menunjukkan sejauh ini banyak pengemudi becak yang tak tertib lalu lintas, yang mengakibatkan terjadinya kecelakaan, oleh karenanya perlu ditertibkan. Selain itu belum ada sanksi bagi pengemudi becak yang diketahui sering melanggar aturan lalu lintas, sehingga membuat perlindungan hukum bagi pihak konsumen maupun pihak ketiga tidak jelas karena adanya kekosongan hukum. Bentuk-bentuk perlindungan yang diharapkan penelitian ini ke depan :

1. Pemerintah Harus melakukan penelitian secara akademis terkait hal tersebut sehingga dapat mengajukan Rancangan Undang-Undang ke pihak Legislatif;

2. Jika kasus kecelakaan yang diakibatkan oleh kelalaian pengemudi Becak yang mengakibatkan kerugian materiil maupun immaterial bagi Pihak Konsumen dan Pihak ketiga yang diajukan kepada kepolisian, Polisi dapat melakukan Diskresi, dan kalau diajukan ke Pengadilan, Hakim dapat menolak ataupun dapat melakukan penemuan hukum untuk mengisi kekosongan hukum

3. Adanya kesadaran masyarakat dan pengemudi becak dalam berlalu lintas untuk melindungi diri sendiri dan konsumen serta menaati peraturan yang berlaku;

4. Membuat aturan tentang sanksi ataupun hal yang terkait dengan kecelakaan untuk memberikan kepastian hukum dan perlindungan bagi Pengemudi 
Becak, Konsumen maupun Pihak Ketiga yang dirugikan secara Materiil maupun Immateriil.

Diharapkan dengan bentuk-bentuk perlindungan ini, akan memberikan masukan akademis terhadap penumpang sebagai korban akibat dari kelalaian pengemudi becak, seperti telah diuraikan di atas, bahwa pengemudi becak telah menerima sanksi hukuman baik ganti rugi secara perdata dan pelaporan kepada pihak kepolisian akan kelalaian pengemudi becak yang mengakibatkan meninggal atau lukanya penumpang, sehingga akibat dari perbuatan lalainya, pengemudi becak tersebut menjalankan hukuman yang telah ditetapkan sebagai bentuk tanggung jawab pidananya

\section{PENUTUP}

Adapun kesimpulan dari artikel ini, adalah Undang-Undang No. 22 Tahun 2009 tentang Lalu Lintas dan Angkutan Jalan tidak mengatur tentang pengoperasian angkutan tradisional becak, namun di tiap-tiap daerah ada yang memperbolehkan beroperasinya angkutan umum roda dua berdasarkan peraturan daerahnya masing-masing sesuai dengan kebutuhan dan eksistensi becak sebagai bagian dari mempertahankan budaya tradisional. Pengemudi becak bertanggung jawab kepada penumpang akibat kelalaiannya yang mengakibatkan meninggal atau luka penumpangnya. Jika kasus kecelakaan yang diakibatkan oleh kelalaian pengemudi becak yang mengakibatkan kerugian materiil maupun immaterial bagi penumpang yang diajukan kepada kepolisian, polisi akan memproses sesuai prosedur, dan melakukan upayaupaya hukum dan pembuktian yang tuntas membuktikan bahwa memang kecelakaan itu akibat dari kelalaian pengemudi becak, dan apabila mampu mengganti kerugian materil dan immateril dari penumpangnya yang menderita akibat kelalaiannya sehingga mengalami kecelakaan. Selain itu juga mempunyai tanggung jawab pidana atas perbuatannya yang mengakibatkan penumpang meninggal atau luka-luka. 
p-ISSN : 2541-2345, e-ISSN : 2580-8842

\section{DAFTAR PUSTAKA}

\section{Buku}

Abdul Kadir Muhammad, Hukum Pengangkutan Niaga, Bandung : PT. Citra Aditya Bakti, 2013.

Dyah Ochtorina Susanti dan A'an Efendi, Penelitian Hukum (Legal Research), Jakarta: Sinar Grafika, 2014.

H.M.N Purwosutjipto, Pengertian Pokok Hukum Dagang Indonesia, Jilid 3, Jakarta: Djambatan, 1995.

Suwardjoko P Wardani, Pengelolaan Lalu Lintas dan Angkutan Jalan, Bandung, 2002.

Peter Mahmud Marzuki, Penelitian Hukum, Jakarta:Kencana, 2007.

Soedjono dan H Abdurahman, Metode Penelitian Hukum, Jakarta: Rineka Cipta, 2003.

Soerjono Soekanto, Pengantar Penelitian Hukum, Jakarta:UI, 2007.

\section{Jurnal}

Baihaqi Hendri Mangatta, Strategi Adaptasi Tukang Becak Dalam Kehidupan Sosial Ekonomi (Studi Kasus Tukang Becak di Kelurahan Bontobiraeng Kecamatan Mamajang Kota Makassar), Jurnal Holistik Tahun IX No. 18/Juli-Desember 2016, Fakultas Ilmu Sosial dan Ilmu Politik Universitas Sam Ratulangi, 2016, Manado.

Meta Suryani dan Anis Mashdurohatun, "Penegakan Hukum Terhadap Eksistensi Becak Bermotor (Bentor) Berdasarkan Undang-Undang Nomor 22 Tahun 2009 Tentang Lalu Lintas dan Angkutan Jalan," Jurnal Pembaharuan Hukum, Volume III No. 1 Januari-April 2016, Fakultas Hukum Universitas Islam Sultan Agung, 2016, Semarang. DOI: http://dx.doi.org/10.26532/jph.v3i1.1341

Putu Agus Jegantara Wiguna, Arinto Nugroho, Aturan Penggunaan Becak Tradisional di Kota Surabaya, Jurnal Novum, Vol. 4. No.1, Fakultas Hukum Universitas Negeri Surabaya, 2017, Surabaya.

Riri Dwi Vivindra, Syamsir dan Nurman, "Eksistensi Bendi dalam Perspektif Budaya di Kota Padang, Provinsi Sumatera Barat, Jurnal Humanus," Vol. XIV No. 1 Tahun 2015, Universitas Negeri Padang, 2015, Padang. DOI: https://doi.org/10.24036/jh.v14i1.5404

Sunaryo, Margianto, dan Usman Ali, Pelestarian dan Pembinaan Usaha Jasa Ojek Dokar dan Becak di Pasar Tradisional Malang, Jurnal Semar Vol. 5 No. 1 November, Universitas Sebelas Maret, 2016, Surakarta. DOI: https://doi.org/10.20961/semar.v5i1.16342 
$p-I S S N$ : 2541-2345, e-ISSN : 2580-8842

Ully Muzakir, Zainal Abidin Suarja, Becak Argo Sebagai Sumber Penghasilan Dan Transportasi Baru Di Kota Madani, Jurnal Genta Mulia Vol VII No 2. Juli-Desember, STKIP Bina Bangsa Meulaboh, 2016, Aceh Barat.

Yuni Astuti, "Eksistensi Angkutan Becak dalam Perkembangan Transportasi di Yogyakarta," Jurnal INA- Rxiv, Intitut Teknologi Bandung, 2016, Bandung. https://doi.org/10.31227/osf.io/b793k

\section{Undang-Undang}

Undang-Undang No. 22 Tahun 2009 Tentang Angkutan dan Lalu Lintas Jalan

\section{Internet}

http://rakyatindependen.com/pengendara-sepeda-motor-scopy-nabrak-becakdari-belakang-di-jalan-raya-kapas/

Kasus tabrakan Becak dan Motor di Yogyakarta, Youtube, https://www.youtube.com/watch?v=X5W7dLXQ8nM

https://id.wikibooks.org/wiki/Profil_Becak_di_Indonesia/Sejarah_perkembangan _becak_di_Indonesia , Sejarah Becak yang Tak Pernah Mati, Diaskes, Tanggal. 1 Agustus 2017

https://id.wikibooks.org/wiki/Profil_Becak_di_Indonesia/Sejarah_perkembangan becak_di_Indonesia, Sejarah Becak, Diaskes, Tanggal. 1 Agustus 2017 https://id.wikibooks.org/wiki/Profil_Becak_di_Indonesia/Sejarah_perkembangan becak_di_Indonesia, Becak Vs Telovaxi, Diaskes, Tanggal. 1 Agustus 2017 https://id.wikibooks.org/wiki/Profil_Becak_di_Indonesia/Sejarah_perkembangan _becak_di_Indonesia, Mengayuh Sejarah Becak, Diaskes, Tanggal. 1 Agustus 2017

http://rakyatindependen.com/pengendara-sepeda-motor-scopy-nabrak-becakdari-belakang-di-jalan-raya-kapas/ 